\title{
Efficacy of Dietary Calcium and Vitamin D Supplementation on Rats with Induced Cerebral Palsy
}

\author{
Hoda S. Ibrahim, Naeem M. Rabeh and Fatma N. Ahmed \\ Nutrition and Food Science Department, Faculty of Home Economics, \\ Helwan University.
}

\begin{abstract}
Cerebral palsy is characterized by motor impairment and can present with global physical and mental dysfunction. The aim of the present study was to investigate the effect of dietary calcium and vitamin D supplementation on rats with induced cerebral palsy. Forty five adult male albino rats weighing $180 \pm 5 \mathrm{gm}$ were divided into seven groups. The 1 st group $(n=6)$ was fed on the basal diet (-ve control). The rest of rats $(n=39)$ were injected with $15 \mu \mathrm{l}$ of ethanol to induce cerebral palsy (CP) and daily ingestion of $20 \mathrm{mg} / \mathrm{kg} . \mathrm{b} . \mathrm{w}$ of sodium phenytoin, 3 rats were sacrified to insure occurrence of $(\mathrm{CP})$.

Other groups were 6 each The $2^{\text {nd }}$ group of rats continues and were fed on basal diet (+ve control). Group 3 was fed on daily basal diet supplemented with vitamin D3 by concentration of $600 \mathrm{IU} \mathrm{kg} / \mathrm{b} . \mathrm{w}$. Groups 4-5 were fed on basal diet supplemented with $40 \mathrm{mg} \mathrm{\& 120} \mathrm{mg} \mathrm{of} \mathrm{calcium} \mathrm{(level1} \mathrm{and} \mathrm{2)} \mathrm{with} \mathrm{addition}$ of vitamin D, respectively. Group 6 was fed on basal diet supplemented with level $1 \mathrm{Ca}$ with vitamin D supplementation, while group 7 was fed on basal diet supplemented with level 2 Ca with vitamin D supplementation. At the end of the experimental period (10 weeks), rats were scarified. Hence, serum calcium, and vitamin D3 were determined. Results indicated that ethanol CP rats showed a significant ( $P$ $<0.05)$ decrease in serum vit.D and serum calcium compared to the negative control one as well as Bone minerals density. It also indicated that supplemented diet with vitamin $D$ and calcium at the highest level improved BWG\% as well as serum vitamin $\mathrm{D}$ and calcium, Also these supplementation increased the bone mineral density. We concluded that Vit.D and Ca supplementation had beneficial effects on CP rats. It could be recommended that Vit.D and Ca supplementation are worthy trying on cerebral palsy patients.
\end{abstract}

Key Words: cerebral palsy, calcium, $25(\mathrm{OH})$ vt.D, bone mineral density ,biochemical analysis of bone mineral, sodium phenytoin .

\section{Introduction}

Cerebral palsy is a group of disorders in the development of movement and posture, causing activity limitation, that is attributed to non-progressive disturbances that occurred in the developing fetal or infant brain (Bax et al., 2005). This group of syndromes ranges in severity and is the result of a variety of etiologies occurring in the prenatal, perinatal or postnatal period. CP is the most common form of chronic motor disability in children. Other causes of disability in children include prolonged immobilization, nutritional factors, pubertal disorder and chronic use of anticonvulsants. All these factors may be related to impairment of normal bone development. Low calcium intake is common in CP patients and may contribute to poor 


\section{Hoda S. Ibrahim et al.,}

mineralization of bone matrix. Consequently, children with severe CP are at risk for developing low bone mineral density (BMD) and low-impact fractures (Loisa et al., 2009).

Children with disabilities that limit mobility are at increased risk for osteoporosis. They often sustain fractures with minimal trauma that impair their function and quality of life (Scheinberg et al., 2015). Additionally, certain medications such as anticonvulsants can increase the fracture risk by altering liver metabolism where $25-\mathrm{OH}$ vitamin D, decreased trabecular bone and increased cortical bone (Zacharin, 2004).Osteoporosis is not only a disease of the elderly, but is increasingly diagnosed in chronically ill children. Children with severe motor disabilities, such as $\mathrm{CP}$, have many risk factors for osteoporosis. Adults with intellectual disability (ID) are also prone to low BMD and increased fractures (Loisa et al., 2009).

Vitamin $D$ is essential for normal skeletal development, mineralization, and growth and for maintenance of skeletal health throughout life, and those assessed vitamin $D$ status and optimal means of improving status in these patient populations Vitamin D promotes calcium absorption from the intestine. Adequate vitamin $\mathrm{D}$ concentrations prevent bone loss and decrease fracture risk in the elderly (Loisa et al., 2009).

Hence this study was conducted to investigate the effect of dietary calcium and vitamin D supplementation on rats with induced cerebral palsy.

\section{Materials and Methods}

\section{Materials:}

Casein, all vitamins, calcium carbonate, minerals, ethanol, L.cystine, choline bitartrate were obtained from El-Gomhoria Company, Cairo, Egypt. Capsules of Cholecalciferol (vitamin D3) at concentration of $1000 \mathrm{IU}$ and sodium phenytoin (PHT) at concentration of $50 \mathrm{mg}$ were obtained from Delmar \& Attallah Pharmacy, Cairo, Egypt.Starch, corn oil, and sucrose were obtained from the local market.Kits for blood analysis were purchased from local distributer (Sigma Chemical), Cairo, Egypt.Animals: A total number of forty five adult male Albino rats (Sprague -Dawley strain) weighing (180 $\pm 5 \mathrm{gm})$ were purchased from the Animal House of Helwan Farm, Helwan, Egypt.

\section{Methods:}

Induction of cerebral palsy in rats:

The left pyramidal tract of adult Sprague-Dawley rats was placed on sterile operation table under intraperitoneal anesthesia. Based on the rat brain stere-otaxic map, a $1-\mathrm{mm}$ hole was made $10 \mathrm{~mm}$ posterior to bregma and $0.8 \mathrm{~mm}$ left of sagittal suture. A microsyringe was inserted perpendicularly to the surface of the brain to a depth of $9.7 \mathrm{~mm}$, and $15 \mu \mathrm{L}$ of ethanol was slowly injected to establish a rat model of spastic cerebral palsy as stated by Yadong et al., (2013). Rats with CP then received phenytoin tablets by concentration of $20 \mathrm{mg} / \mathrm{ml} / \mathrm{kg}$ b.w to alleviate the symptoms of CP.

\section{Diet composition and experimental animal design:}

The basal diet was formulated according to AIN-93M diet (Reeves, et al., 1993). Calcium phosphate and phenytoin were dissolved in distilled water and received by oral tube according to body weight of rats. Capsules of cholecalciferol (vitamin D3) was dissolved in corn oil and administrated with oral tube according to body weight of rats. 


\section{Egypt. J. of Nutrition and Health Vol. 14 No. 1 January (2019)}

Forty five adult male Albino rats were housed in well- aerated cages under hygienic conditions and were fed on the basal diet for one week for adaptation. After this period rats were divided into groups as follows:- The first main group ( 6 rats) was fed on basal diet and served as a negative control group (-ve). The second group (39 rats) was injected with $15 \mu \mathrm{L}$ of ethanol for induction of $\mathrm{CP}$. Three rats were scarified and the femur bone was taken to insure the induction of the CP using DEXA examination. Then the rest of the rats were divided into six subgroups (6 rats each) as follows:

Subgroup (2):

Subgroup(3):

Subgroup(4):

Subgroup(5):

Subgroup(6):

Subgroup(7):
Rats with CP were fed on basal diet (+ve control).

Rats with CP were fed on basal diet and given daily orally vitamin D3 (600 IU/ kg.b.w). Rats with CP were fed on daily basal diet supplemented with $40 \mathrm{mg}$ calcium (level1). Rats with CP were fed on daily basal diet supplemented with $120 \mathrm{mg}$ calcium (level 2). Rats with CP were fed on daily basal diet supplemented with 40 mg calcium (level1) in addition to daily vitamin D.

Rats with CP were fed on daily basal diet supplemented with120 mg calcium (level2) in addition to daily vitamin $\mathrm{D}$.

At the end of experimental period (10 weeks) rats were anesthetized with diethyl ether after fasting for $12 \mathrm{~h}$ and blood samples were taken then serum was carefully separated into vacuum tubes and kept frozen until biochemical analysis. Femur bones were removed from each rat for DEXA analysis.

Biological Evaluation: feed intake (FI), feed efficiency ratio (FER) and body weight gain percent (BWG\%) were determined according to Chapman et al., (1959) using the following equation:

Final body weight $(\mathrm{g})$ - Initial body weight $(\mathrm{g})$
Initial body weight $(\mathrm{g})$

FER $=$ Body weight gain $(\mathrm{g}) /$ Feed intake $(\mathrm{g})$

Biochemical Analysis: Serum calcium content was determined according to Gosling, (1986).Serum vitamin $D$ was determined by enzyme linked immunosorbent assay (ELISA) according to the method described by Zerwekh(2008).

Bone mineral density: The density of bone in the right femur was determined by DEXA UNITE (LUNAR OX IQ 4716) according to the method of EL- Adawy, (1986)

Statistical Analysis: the results were expressed as means \pm Standard Error (SE).The obtained results were analyzed according to SPSS program, Version (20). ANOVA test was used to compare results among groups and $\mathrm{P}<0.05$ was considered to be significant (Snedecor and Cochran, 1980).

\section{Results}

Results illustrated in Table (1) show the effect of diet supplemented with calcium and vitamin D on body weight gain and feed efficiency ratio of cerebral palsy rats. There was significant $(P<0.05)$ decrease in the positive control (CP rats) compared to the negative control one. Diet supplemented with calcium or with vitamin D separately or in- combination led to significant increase in body weight gain \%, compared to the positive control group. It was also observed that the highest body weight gain $\%$ was 


\section{Hoda S. Ibrahim et al.,}

recorded for the group that fed on high calcium level $(120 \mathrm{mg})$ with vitamin D. Moreover, the mean feed intake was increased at all different treated groups compared to the positive control group.

Results in Table (1) also revealed that the FER of the positive control group was significantly $(\mathrm{P}<$ $0.05)$ decreased compared to the negative control group. FER for all treated groups was significantly $(\mathrm{P}<0.05)$ increased compared to the positive control group. It was also observed that there were no significant differences in FER among the groups ingested $40 \mathrm{mg}$ calcium separately or with vitamin D supplementation in the diet as compared to the negative control group.

Table (1)

Effect of diets supplemented with Ca and vitamin D on body weight and FER of Cerebral Palsy rats.

\begin{tabular}{l|c|c|c|c}
\hline \multirow{2}{*}{\multicolumn{1}{c|}{ Groups }} & \multicolumn{3}{|c|}{ Parameters } & \\
\cline { 2 - 5 } Control (-ve) & BWG\% & BWG (gm) & Fl(g/day/rat) & FER \\
\hline Control (+ve) & $43.13 \pm 1.76^{\mathrm{a}}$ & 79.1 & 19.10 & $0.05 \pm 0.001^{\mathrm{a}}$ \\
\hline Vit. D & $5.27 \pm 0.48^{\mathrm{e}}$ & 9.6 & 11.00 & $0.01 \pm 0.0009^{\mathrm{d}}$ \\
\hline level 1,(40 mg Ca) & $13.84 \pm 1.04^{\mathrm{d}}$ & 25 & 13.70 & $0.02 \pm 0.001^{\mathrm{c}}$ \\
\hline level 2, (120 mg Ca) & $29.88 \pm 2.28^{\mathrm{c}}$ & 55.3 & 14.00 & $0.05 \pm 0.004^{\mathrm{ab}}$ \\
\hline level 1 Ca +Vitamin D & $30.00 \pm 2.71^{\mathrm{c}}$ & 54.9 & 15.00 & $0.04 \pm 0.002^{\mathrm{b}}$ \\
\hline level 2 Ca +Vitamin D & $35.71 \pm 2.23^{\mathrm{b}}$ & 65.4 & 15.50 & $0.04 \pm 0.003^{\mathrm{ab}}$ \\
\hline
\end{tabular}

${ }^{*}$ Values are expressed as means \pm SEM.

*Values at the same column with different letters are significantly different at $\mathrm{P}<0.05$.

*BWG:body weight gain,FI :feed intake,FER: feed efficacy ratio

The concentrations of serum vitamin $D$ are recorded in Table (2). There was a significant $(P<0.05)$ decrease in serum vit. $D$ levels for the positive control group compared to the normal negative control group. However, serum vit.D levels was significantly $(P<0.05)$ increased among all treated groups compared to the positive control group. Results indicated that rats with $\mathrm{CP}$ and ingested vitamin $\mathrm{D}$ had significantly increase serum vitaminD concentration compared with the $\mathrm{CP}$ rats fed on normal diet (group 3).On the other hand It was observed that, the diet supplemented with $120 \mathrm{mg}$ calcium or vitamin D with calcium at level $1(40 \mathrm{mg})$ caused no significant difference in the serum concentration of vitamin $D$ compared to the negative control group. The highest increase in serum vitamin $D$ concentration was observed at the group of rats fed on calcium at the highest level with vitamin $D$ addition. Thus, our study showed that ingestion of vitamin $D$ and calcium at the highest level improved serum vitamin $\mathrm{D}$ concentration of cerebral palsy rats . 
Egypt. J. of Nutrition and Health Vol. 14 No. 1 January (2019)

Table (2)

Effect of diets supplemented with Ca and vitamin D on serum concentration of vitamin D in rats with Cerebral Palsy

\begin{tabular}{l|c}
\hline Groups & Vitamin D (nmol/L) \\
\hline Control(-Ve) & $50.56 \pm 4.26^{\mathrm{b}}$ \\
\hline Control(+V) & $13.13 \pm 1.24^{\mathrm{e}}$ \\
\hline Vitamin D & $29.39 \pm 1.37^{\mathrm{d}}$ \\
\hline Level (1) $40 \mathrm{mg} \mathrm{Ca}$ & $35.76 \pm 2.90^{\mathrm{dc}}$ \\
\hline Level (2) $120 \mathrm{mg} \mathrm{Ca}$ & $44.36 \pm 2.04^{\mathrm{cb}}$ \\
\hline Level (1) Ca +Vitamin D & $53.05 \pm 1.80^{\mathrm{b}}$ \\
\hline Level (2) Ca +Vitamin D & $66.10 \pm 4.84^{\mathrm{a}}$ \\
\hline
\end{tabular}

Values are expressed as means \pm SE.

Values at the same column with different letters are significantly different at $\mathrm{P}<0.05$.

Regarding serum calcium in table (3) CP rats(group 2) had significant decrease $(P<0.05)$ in the concentrations of serum calcium compared to the negative control group (normal rats). Diet supplemented with vitamin $D$ or calcium at the two different levels separately or in-combination with vitamin $D$ showed significant $(P<0.05)$ increase in the concentration of serum calcium compared to the positive control group. There was no significant change in serum $\mathrm{Ca}$ among all treated rats with $\mathrm{Ca}$ at the two tested level separately or in-combination with vitamin D.

Table (3)

Effect of diet supplemented with $\mathrm{Ca}$ and vitamin $\mathrm{D}$ on serum calcium in rats with cerebral palsy

\begin{tabular}{l|c}
\hline \multicolumn{1}{c|}{ Groups } & Calcium $(\mathrm{mg} / \mathrm{dl})$ \\
\hline Control(-Ve) & $11.20 \pm 1.02^{\mathrm{a}}$ \\
\hline Control(+Ve) & $4.14 \pm 0.64^{\mathrm{d}}$ \\
\hline Vitamin D & $7.12 \pm 0.12^{\mathrm{c}}$ \\
\hline Level (1) 40 mg Ca & $8.21 \pm 0.19^{\mathrm{cb}}$ \\
\hline Level (2) $120 \mathrm{mg} \mathrm{Ca}$ & $8.10 \pm 0.11^{\mathrm{cb}}$ \\
\hline Level (1) Ca +Vitamin D & $9.60 \pm 0.55^{\mathrm{b}}$ \\
\hline Level (2) Ca +Vitamin D & $9.25 \pm 0.21^{\mathrm{b}}$ \\
\hline${ }^{*}$ Values are expressed as means + SE
\end{tabular}

*Values are expressed as means \pm SE.

*Values at the same column with different letters are significantly different at $\mathrm{P}<0.05$.

Effect of diet supplemented with calcium and vitamin D on DEXA Scan of cerebral palsy rats was shown in Table (4). The mean bone mineral density of the positive control group was significantly $(P<0.05)$ decreased, compared to the negative control rats. The diet supplementation with vitamin $\mathrm{D}$ or calcium at the two different levels separately or in combination with vitamin $D$ showed significant $(P<0.05)$ increase the mean value of bone mineral density, compared to the positive control group. There was no significant change in bone mineral density between the groups given calcium in the diet either at low or high level. However, there was a significant increase in bone mineral density for rats given calcium at high level with vitamin $\mathrm{D}$ addition compared to either the rats given calcium at the lwo level with of vitamin $\mathrm{D}$ or rats given vitamin $\mathrm{D}$ alone. The highest BMD was observed for the groups given calcium at high level with vitamin $\mathrm{D}$ supplementation. 
Table (4):

Effect of diet supplemented with Ca and vitamin D on Bone Mineral

Density in rats with cerebral palsy

\begin{tabular}{l|c}
\hline \multicolumn{1}{c|}{ Groups } & Bone Minerals Density $\left(\mathrm{g} / \mathrm{Cm}^{2}\right)$ \\
\hline Control(-Ve) & $0.08 \pm 0.003^{\mathrm{d}}$ \\
\hline Control(+Ve) & $0.07 \pm 0.001^{\mathrm{e}}$ \\
\hline Vitamin D & $0.09 \pm 0.001^{\mathrm{cd}}$ \\
\hline Level (1) $40 \mathrm{mg} \mathrm{Ca}$ & $0.10 \pm 0.002^{\mathrm{cb}}$ \\
\hline Level (2) $120 \mathrm{mg} \mathrm{Ca}$ & $0.10 \pm 0.006^{\mathrm{b}}$ \\
\hline Level(1) Ca +Vitamin D & $0.10 \pm 0.003^{\mathrm{b}}$ \\
\hline Level(2) Ca +Vitamin D & $0.11 \pm 0.002^{\mathrm{a}}$ \\
\hline
\end{tabular}

${ }^{*}$ Values are expressed as means \pm SEM.

*Values at the same column with different letters are significantly different at $\mathrm{P}<0.05$.

\section{Discussion}

Children with $\mathrm{CP}$ are at risk for developing low bone quality and low-impact fractures. Important risk factors compromising bone health in this group are immobility, malnutrition and medication use e.g. antiepileptic drugs (Papadeliset al., 2018). Children with severe CP develop over the course of their lives clinically significant osteopenia. Unlike elderly adults, this is not primarily from true losses in bone mineral, but from a rate of growth in bone mineral that is diminished relative to healthy children (Henderson et al., 2005).

Henderson et al., (2002) found that the risk factors for lower bone mineral density in the distal femur of children with disabilities include severity of neurological impairment, increased feeding difficulty, use of anticonvulsants, and lower triceps skin-fold measurement.

The obtained results indicated that diet supplemented with vitamin $D$ and calcium at the two studied levels significantly $(\mathrm{P}<0.05)$ improved the mean levels of serum $\mathrm{Ca}$, and vitamin $\mathrm{D}$ in $\mathrm{CP}$ rats.Studies examining the effect of calcium with/without vitamin $\mathrm{D}$ supplementation on BMD, fracture risk, or orthopedic complications in individuals with CP are notably lacking. Small, retrospective studies of fracture rates in children and a few young adults with CP have cited the risk factors of poor nutrition and low calcium intake in those who experienced fractures (Chad et al., 1999; Henderson et al., 2002 and Bischof et al., 2002). Other studies have found no statistical difference in the calcium intake of a group of CP patients with fractures compared to age-matched controls without fractures (Presedo et al., 2007). Cayirand Turan, (2014) reported that vitamin $D$ intake decreases stroke frequency in children diagnosed with migraine between the ages of 8 and 16 who are undergoing treatment with both vitamin $D$ and amitriptilin.Dual-energy $\mathrm{X}$-ray absorptiometry is most commonly used as diagnostic method for assessing bone quality. Calcium and vitamin D, are critical regulators of bone remodeling (Choi and Seo, 2013 and Lu et al., 2013), promoting weight-bearing activity are also preventive measures that require attention in the care for children and adults with CP (Papadelis et al., 2014).

The results of the current study indicated that supplementation with vitamin $D$ and calcium at the two studied levels significantly improved the mean level of bone mineral density in CP rats. Fractures correlated with low BMD, stiff joints, poor balance, and violent seizures (Brunner and Doderlein, 1996). Mergler et al., (2009) confirms that low BMD is a serious problem in children with severe CP, significant determinants of low BMD were limited ambulation feeding difficulties, previous fracture, anticonvulsant use, and lower fat mass (measured at the triceps skinfold). Kilpinen-Loisa et al., (2010) and Finbratenet al., 


\section{Egypt. J. of Nutrition and Health Vol. 14 No. 1 January (2019)}

(2015) suggested that most children with motor disability have low BMD and subsequently increased susceptibility to fractures were agreement with the present study. Stevenson et al., (2006) have demonstrated an association between better growth and nutrition in CP to be strongly associated with health. since Vit.D and Ca supplementation had beneficial effects on $\mathrm{Cp}$ rats. It could be recommended that Vit.D and Ca supplementation are worthy trial on cerebral palsy patients.

\section{References}

Bax, M.; Goldstein, M.; Rosenbaum, P.; Leviton, A.; Paneth, N.; Dan, B. and Damiano, D. (2005):

Proposed definition and classification of cerebral palsy, April 2005. Developmental medicine and child neurology, 47(8):571-576.

Bischof, F.; Basu, D. and Pettifor, J. (2002):

Pathological long-bone fractures in residents with cerebral palsy in a long-term care facility in South Africa. Dev Med Child Neurol;44:119-22.

Brunner, R. and Doderlein, L. (1996):

Pathological fractures in patients with cerebral palsy., J PediatrOrthop B; 5: 232-8.

Cayir, M. and Turan, H. (2014):

Effect of vitamin D therapy in addition to amitriptyline on migraine attacks in pediatric patients'. Braz J Med Biol Res, (47):349-354.

Chad, K.; Bailey, D.; McKay, H.; Zello, G. and Snyder, R. (1999):

The effect of a weight-bearing physical activity program on bone mineral content and estimated volumetric density in children with spastic cerebral palsy. J Pediatr;135:115-7.

Chapman, D.G.; Castilla, R. and Campbell, J.A. (1959):

evaluation of protein in foods, a method for the determination of protein efficiency ratio. Can $\mathrm{J}$ Biochem. Phys. 37:679-86.

Choi, M. and Seo, J. (2013):

' Effect of taurine feeding on bone mineral density and bone markers in rats'. AdvExpBiol Med. ( 776): 51-58.

El- Adawy, A. (1986):

Msc studies on some acoustical and physical properties of yttria stabilized zirconia refractories before and after irradiation. Fac. Sci, Men.,Univ., 77-110.

Finbraten, A.; Syversen, U.; Skranes, J.; Andersen, G.; Stevenson, R. and Vik, T.(2015):

Bone mineral density and vitamin $\mathrm{D}$ status in ambulatory and non-ambulatory children with cerebral palsy. Jan;26(1):141-50.

Gosling, P. (1986):

Analytical reviews in clinical biochemistry: calcium measurement. Annals of clinical biochemistry, 23(2), 146-156. 


\section{Hoda S. Ibrahim et al.,}

Henderson, R; Kairalla, J.; Barrington ,J.; Abbas , A. andStevenson, R.(2005):

Longitudinal changes in bone density in children and adolescents with moderate to severe cerebral palsy. J Pediatr (6):769-75.

Henderson, R.; Lark, K.; Gurka, J.; Worley, G.; Fung, E.; Conaway, M.; Stallings, V. and Stevenson, R. (2002):

Bone density and metabolism in children and adolescents with moderate to severe cerebral palsy. Pediatrician;110:439-43

Kilpinen-Loisa,P. Paasio, T. Soiva, M. Ritanen, U. Lautala, P. Palmu, P. Pihko, H. Mäkitie, O. (2010): "Low bone mass in patients with motor disability: prevalence and risk factors in 59 Finnish children." Dev Med Child Neurol. 52(3):276-82.

Loisa P.; Pihko H.; Vesander U.; Paganus A.; Ritanen U. and Mäkitie O. (2009): Insufficient energy and nutrient intake in children with motor disability; 98(8): 1329-33.

Lu,M.; Famebo, L.; Branstrom, R. and Larsson, C. (2013): Inhibition of parathyroid hormone secretion by caffeine in human parathyroid cells. $J$ ClinEndocrinolMetab. 98(8): 1345-1351.

Mergler, S.; Evenhuis, H.M.; Boot, A.M.; De Man, S. A.; BindelsdeHeus, K.G.; Huijbers, W.A., and Penning, C. (2009):

Epidemiology of low bone mineral density and fractures in children with severe cerebral palsy: a systematic review. Developmental Medicine \& Child Neurology, 51(10):773-778.

Papadelis, C.; Butler, E.E.; Rubenstein, M.; Sun, L.; Zollei, L.; Nimec, D. and Grant, P.E. (2018): Reorganization of the somatosensory cortex in hemiplegic cerebral palsy associated with impaired sensory tracts. Neurolmage: Clinical, 17:198-212.

Presedo, A., Dabney, K., Freeman, M.,(2007). Fractures in patients with cerebral palsy. J Pediatr Orthop;27:147e53.

Papadelis, C., Ahtam, B., Nazarova, M., Nimec, D., Snyder, B., Grant, P. E., \& Okada, Y. (2014). Cortical somatosensory reorganization in children with spastic cerebral palsy: a multimodal neuroimaging study. Frontiers in human neuroscience, 8, 725.

Reeves, P.G.; Nielsen F.H. and Fahmy G.G. (1993):

AIN-93. Purified diets for laboratory rodents : Final report of the American Institute of Nutrition adhocwriling committee on the reformulation of the AIN-76 A Rodent diet. J. Nutrition, 123: 1939151.

Scheinberg, M.A.; Golmia, R. P.; Sallum, A. M.; Pippa, M.G. ; Cortada, A. P. and Silva, T.G .(2015). Bone health in cerebral palsy and introduction of a novel therapy. Einstein (Sao Paulo), 13(4):555559.

Snedecor, G.W. and Cochran, W. (1980):

Statistical methods.,7th Ed., lowa State University Press, Ames, USA, Page 90. 


\section{Egypt. J. of Nutrition and Health Vol. 14 No. 1 January (2019)}

Stevenson, R. Conaway, M. and Chumlea, W. (2006):

Growth and health in children with moderate-to-severe cerebral palsy.Pediatrics,8.

Yadong Yu.; M.D., Liang L.; Xinzhong S.; Fangtao T. and Qinglu S. and et al., (2013):

Establishing a rat model of spastic cerebral palsy by targeted ethanol injection. Neural Regen Res.

Zacharin M. (2004):

Current advances in bone health of disabled children. Curr Opin Pediatr; 16:545-551.

\section{Zerwekh J.(2008):}

Blood biomarker of vitamin D status .78 (4).Medline

فعالية التدعيم الغذائي بالكالسيوم وفيتامين د على الجرذان المصابة بالثلل الاماغي

هدى سلامة ابراهيم , نعيم حمحم رابح ,فاطمة ناصر احمد

كلية الاقتصاد المنزلي , قسم التغذية وعلوم الاطعمة , جامعة حلوان

الملخص العربي

تهدف الدراسة الحالية الى معرفة كفاءة التدعيم بالكالسيوم وفيتامين د على الجرذان المصابة بالثلل

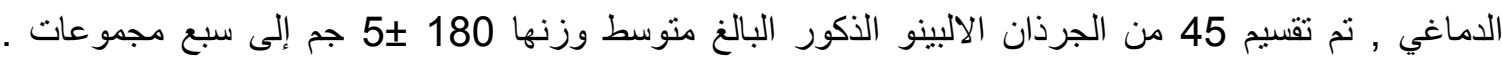
المجموعة الاولى الضابطة السالبة تم تغذيتها على النظام الغذائي الاساسي , ونم حقن المجموعات من الثانية الى الى السابعة بجر عة من الايثانول مقدار ها 15 ميكرولتر لاحداث مرض الثنلل الدماغي و ايضا تم اعطائهم جرعة من فينوتين الصوديوم مقدارها 50 ملجم /كجم من وزن الجرذان للسيطرة على اعراض الثنلل الدماغي , المجموعة

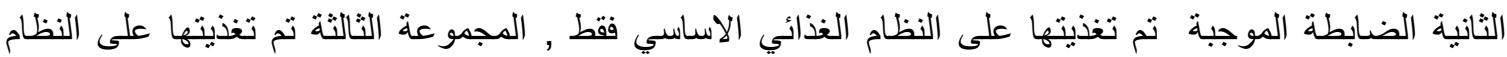
الغذائي الاساسي مدعم بجر عة من فيتامين د مقدار ها 600 وحدة دولية /كجم من وزن الجسم , المجموعات الر ابعة و الخامسة تم تغذيتهم بالنظام الغذائي الاساسي مدعم بمستوبين مختلفين من الكالسيوم 40 و 120 على التو الي , المجموعة السادة نم تغذيتها على النظام الغذائي الاساسي و المستوى الاول من الكالسيوم 40 ملجم مع فيتامين د

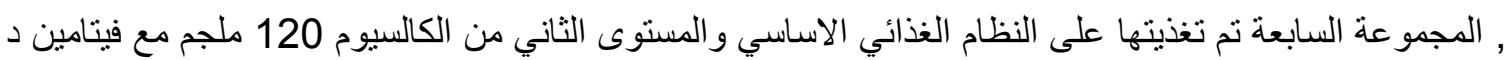
ـ في نهاية 10 أسابيع من مدة التجربة تم قتل الجرذان للحصول على السيرم وتم اجراء التحاليل البيوكيميائية لقياس تركيز الكالسيوم وفيتامين د3 ـ أشنارت النتائج الى وجود فروق معنوية بصورة منخفضة في المجموعة الضابطة

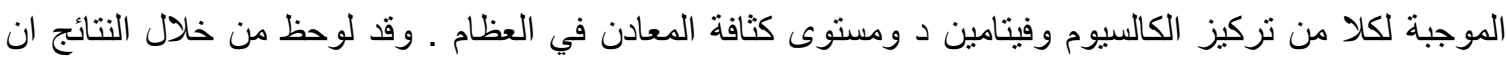

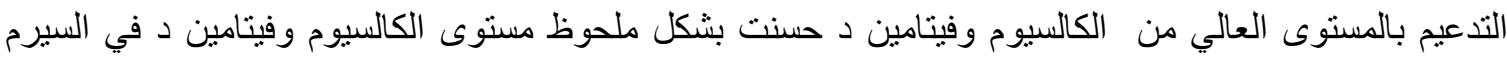
و ايضا مستوى كثافة المعادن في العظام للجرذان المصابة بالثنلل الدماغي ومن ذلك نخلص الى ان التدعيم بمكملات

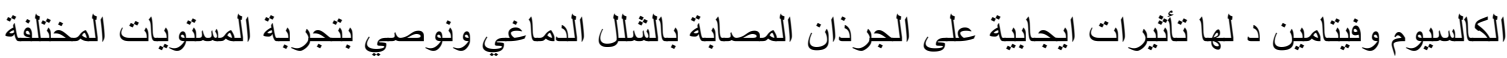

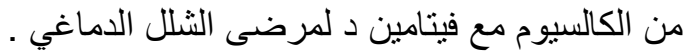

